\title{
TUMOR NECROSIS FACTOR-ALPHA AS DIFFERENTIAL DIAGNOSTIC MARKER FOR PATIENTS WITH FEVER OF UNKNOWN ORIGIN
}

Biljana Popovska-Jovicic ${ }^{1}$, Ivana Rakovic ${ }^{1}$, Sara Petrovic ${ }^{1}$, Petar Canovic ${ }^{2}$, Dejan Petrovic ${ }^{3}$, Sofija Sekulic ${ }^{1}$, Ivan Jovanovic ${ }^{4,5}$ and Nemanja Jovicic ${ }^{6}$ ${ }^{1}$ Department of Infectious diseases, Faculty of Medical Sciences, University of Kragujevac, Serbia ${ }^{2}$ Department of Biochemistry, Faculty of Medical Sciences, University of Kragujevac, Serbia ${ }^{3}$ Department of Internal medicine, Faculty of Medical Sciences, University of Kragujevac, Serbia ${ }^{4}$ Department of Microbiology and immunology, Faculty of Medical Sciences, University of Kragujevac, Serbia ${ }^{5}$ Center for Molecular Medicine and Stem Cell Research, Faculty of Medical Sciences, University of Kragujevac, Serbia

${ }^{6}$ Department of Histology and embryology, Faculty of Medical Sciences, University of Kragujevac, Serbia

\section{FAKTOR NEKROZE TUMORA-ALFA KAO DIFERENCIJALNO DIJAGNOSTIČKI MARIKER U EVALUACIJI FEBRILNIH STANJA NEPOZNATOG POREKLA}

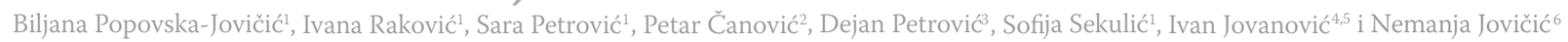 \\ ${ }^{1}$ Katedra za Infektivne bolesti, Fakultet medicinskih nauka, Univerzitet u Kragujevcu, Srbija \\ ${ }^{2}$ Katedra za Biohemiju, Fakultet medicinskih nauka, Univerzitet u Kragujevcu, Srbija \\ ${ }^{3}$ Katedra za Internu medicinu, Fakultet medicinskih nauka, Univerzitet u Kragujevcu, Srbija \\ ${ }^{4}$ Katedra za Mikrobiologiju i imunologiju, Fakultet medicinskih nauka, Univerzitet u Kragujevcu, Srbija \\ ${ }^{5}$ Centar za Molekulsku medicinu i istraživanje matičnih ćelija, Fakultet medicinskih nauka, Univerzitet u Kragujevcu, Srbija \\ ${ }^{6}$ Katedra za histologiju i embriologiju, Fakultet medicinskih nauka, Univerzitet u Kragujevcu, Srbija
}

Received / Primljen: 04. 04. 2017

\section{ABSTRACT}

Febrile conditions of unidentified origin are still unknown in modern medicine despite the development of diagnostic procedures. There are various agents of long-term temperature encompassing numerous infectious or non-infectious diseases.

The aim of this study was to determine if there was a statistically significant difference in the values of proinflammatory cytokines (IL-1, TNFa, IL-6) in patients who meet the criteria for febrile conditions of unidentified origin, between the group of infectious, malignant, rheumatic, "other" diseases and undiagnosed patients.

The study was conducted in the Immunology laboratory of the Center for Molecular Medicine and Stem Cells Research of the Faculty of Medical Sciences in Kragujevac. Blood samples were taken from patients tested at the Clinic for Infectious Diseases, of the Clinical Center of Kragujevac, in the period from 2014 to 2016. The study included 70 patients.

The measured values of the level of TNFa showed significantly higher values in a group of malignant diseases than in the group of infectious diseases, while the values of IL-1 and IL-6 did not show statistical significance.

TNF $\alpha$ can improve diagnosing in case of patients with an unknown febrile condition, which can shorten the length of the hospital stay and reduce the volume of performance of diagnostic procedures.

Keywords: temperature, temperature of an unknown cause, IL-1, TNF $\alpha$, IL-6

\section{SAŽETAK}

Accepted / Prihvaćen: 18. 05. 2017

Febrilna stanja nepoznatog porekla i dalje predstavljaju nepoznanicu u savremenoj medicini i pored razvoja dijagnostičkih procedura. Uzročnici dugotrajne temperature mogu biti različiti, obuhvatajući brojne infektivne ali i neinfektivne bolesti.

Cilj istraživanja je bio da utvrdimo da li postoji statistički značajna razlika u vrednostima proinflamatornih citokina (IL- 1, TNFa, IL-6) kod bolesnika koji ispunjavaju kriterijume za febrilna stanja nepoznatog porekla, izmedu grupe infektivnih, malignih, reumatoloških, „drugih” bolesti $i$ nedijagnostikovanih bolesnika.

Istraživanje je rađeno u Imunološkoj laboratoriji Centra za molekulsku medicinu i istraživanja matičnih ćelija Fakulteta medicinskih nauka u Kragujevcu. Krv za analizu uzeta je od bolesnika ispitivanih na Klinici za infektivne bolesti, Kliničkog Centra Kragujevac, u periodu od 2014. godine do 2016. godine. U ispitivanju je učestvovalo 70 bolesnika.

Izmerene vrednosti nivoa TNF $\alpha$ su pokazale statistički značajno više vrednosti u grupi malignih bolesti u odnosu na grupu infektivnih bolesti, dok vrednosti IL-1i IL-6 nisu pokazale statističku značajnost.

TNFa može unapredi postavljanje dijagnoze kod bolesnika sa nejasnim febrilnim stanjem, čime se može skratiti trajanje hospitalizacije $i$ smanjiti obim izvodenja dijagnostičkih procedura.

Ključne reči: temperatura, temperatura nepoznatog uzroka, IL- 1, TNF $\alpha, I L-6$

\section{ABBREVIATIONS}

ELISA - engl. enzyme-linked immunosorbent assay IL - interleukin (engl. interleukin) FUO - febrilna stanja nepoznatog uzorka (engl. Fever of unknown origin)

${ }^{18}$ F-FDG - 2-deoxy-2-( $\left.{ }^{18} F\right)$ fluoro-D-glucose PET - pozitronska emisiona tomografija (engl. Positron
PGE2 - prostaglandin E2

serr - standardna greška (engl. standard error)

SD - standardna devijacija (engl. standard deviation)

TNF- $\alpha$ - faktor nekroze tumora- $\alpha$ (engl. tumor necrosis factor- $\alpha)$

TRAIL - (eng. TNF related apoptosis-inducing ligandTRAIL)

Corresponding author: Biljana Popovska-Jovičić Svetozara Markovića 69, 34000 Kragujevac E-mail: biljanapop@yahoo.com 


\section{INTRODUCTION}

In the pathogenesis of fever, proinflammatory cytokines IL-1, IL-6, and TNF have an important role which, by circulating from sites of infection or inflammation, go to the blood brain barrier in the hypothalamus $(1,2,3)$. On endothelial cells of the preoptic region of the hypothalamus they are band to their receptors and they induce the formation of prostaglandin E2 (PGE2), which is the main pyrogenic mediator in the genesis of elevated temperature $(4,5)$.

Tumor necrosis factor (TNF) is a proinflammatory cytokine that shares many biological similarities with IL-1, which is a result of the activation of the same transcription factors, despite the existence of structural and receptor differences (6). It represents a mediator of acute inflammatory response and is responsible for many systemic complications during the infection $(7,8)$. TNF in the case of a large production may have a number of system effects, and thus causes the loss of myocardial contractility and the inhibition of the tone of blood vessels, which has a role in the development of shock (9). It stimulates endothelial cells to express the activators of coagulation and to inhibit the expression of thrombomodulin coagulation inhibitor, which consequently leads to the formation of intravascular thromboses $(10,11,12)$. It is believed that TNF $\alpha$ mediates in oncogenesis, by activating the transcription of the pro-inflammatory transcription factor NF- $\mathrm{kB}$, which allows expression of genes associated with tumor survival, proliferation, invasion, angiogenesis and metastasis (13).

Febrile condition of unidentified origin represents a special condition that refers to an elevated temperature above $38.3^{\circ}$, which is registered on several occasions, and lasts longer than three weeks without any diagnoses despite an adequate testing during three visits to the doctor that is after a three-day stay at the hospital. (14). There are various agents of unclear febrile conditions and they include a large number of clinical entities. Petersdorf and Besson described four groups of diseases and divided them according to the etiological agents (15). The division has been valid nowadays as well, and it comprises: infectious, malignant, and other rheumatic diseases involving granulomatous diseases, subacute thyroiditis, inflammatory bowel diseases, drug-induced temperature and artificially induced temperature (16-18).

It has been discovered that some of the proinflammatory cytokines have a role of endogenous pyrogens, while on the other hand, certain cytokines can have antipyretic effect. (19) Some of these circulating proteins are mediating intracellular communication between the immune and nervous systems, which is the reason why the cytokine profile is under examination in this study (20).

\section{PATIENTS AND METHOD}

Testing of the cytokine profile was done in Immunological laboratory of the Center for Molecular Medi- cine and Stem Cells Research of the Faculty of Medical Sciences in Kragujevac. Blood samples taken from patients were tested at the Clinic for Infectious Diseases, of the Clinical Center of Kragujevac, in the period from 2014 to 2016. 70 patients participated in the study. FUO group of patients, involved 38 patients who met the criteria for febrile conditions of unknown etiology (22) which comprises: a) a repeated appearance of the temperature over $38.3^{\circ} \mathrm{C}$ within three weeks; b) the origin of temperature remains unresolved after three visits to the doctor of the ambulance service that is three days of hospital tests. The control group included hospitalized patients diagnosed with any of the preexisting acute infectious diseases, of a viral or bacterial etiology. The study included 32 patients.

The aim of this study was to determine whether there is a statistically significant difference in the values of proinflammatory cytokines (IL-1, TNF $\alpha$, IL-6) between the group of infectious, malignant, rheumatic, "other" diseases and undiagnosed patients.

a) Determining the concentration of the cytokine in the serum

Blood samples, with the amount of $10 \mathrm{ml}$, were taken before treatment. The blood sample was centrifuged at $2000 \mathrm{rpm}$ for 5 minutes. After the centrifugation serum was separated and distributed in 3-5 tubes. The tubes were labeled and serum sample was stored at -20 - $C$. For determining serum level of cytokines, IL-1 $\beta$, IL-6, TNF $\alpha$, commercial ELISA kits (R\&D Systems, Minneapolis, MN, USA) have been used.

For performing the ELISA test manufacturer's manual was used. Optical density was read on a microplate reader (ZENYTH 3100 MyLTi-Mode Detector, Anthos, Austria) at a wavelength of $450 \mathrm{~nm}$.

Measured values of absorbance have, before the analysis, been decreased for the value of the absorbance of blind probe (deionized water). The reading values of the standard were used to construct a standard curve, and then equation was determined according to which concentration of the tested cytokines was calculated.

b) Statistical data processing

Data were analyzed using the statistical program SPSS version 22. For describing the linear relationship between two variables Pearson linear correlation coefficient $r$ was used as well as Spearman's rank correlation coefficient rho. Results of the study and experiments are expressed as an average value $+/$ - standard error (SE) or standard deviation (SD). For a statistically significant difference in the values obtained between groups, we used the two levels of statistical significance: statistically significant difference $\mathrm{p}<0.05$ and highly statistically significant difference $\mathrm{p}<0.01$. The obtained results are presented in tables and graphs. 


\section{RESULTS}

The study included 70 patients who were examined and treated at the Clinic for Infectious Diseases, of the Clinical Center of Kragujevac. Criteria for unclear febrile conditions were met by 38 patients. After the diagnosis, FUO patients were classified according to the etiology into infectious and non-infectious group of diseases. 11 patients (29\%) were diagnosed with some of the infectious diseases, whereas 24 of FUO patients (63\%) were diagnosed with non-infectious disease. In 3 patients (8\%) after exhausting all diagnostic procedures the cause of febrile condition was not discovered, and they belonged to a group of undiagnosed patients. 10 of rheumatic patients (26\%), 9 who were diagnosed with malignancy (23\%), and $5(13 \%)$ patients who belong to the group of "other diseases" belonged to the group of non- infective agents of FUO (Figure 1).
The control group consisted of 32 patients who were diagnosed with some of the acute infectious diseases.

The results showed that there was no statistically significant difference in the levels of IL-1ß serum between two groups. Values of IL-1ß in the group of FUO patients were approximately equal to values which were measured in patients with acute infectious diseases, and in the study they represented the control group. The average value of IL-1 $\beta$ in the group of rheumatic diseases was higher than the control group, but there was not a statistically significant difference (Figure 2).

Tumor necrosis factor is a proinflammatory cytokine that shares many biological similarities with IL-1. In the group of FUO patients there was a trend of increasing serum levels of TNF $\alpha$ as opposed to patients diagnosed with acute infectious diseases, but not any statistical significance was achieved.

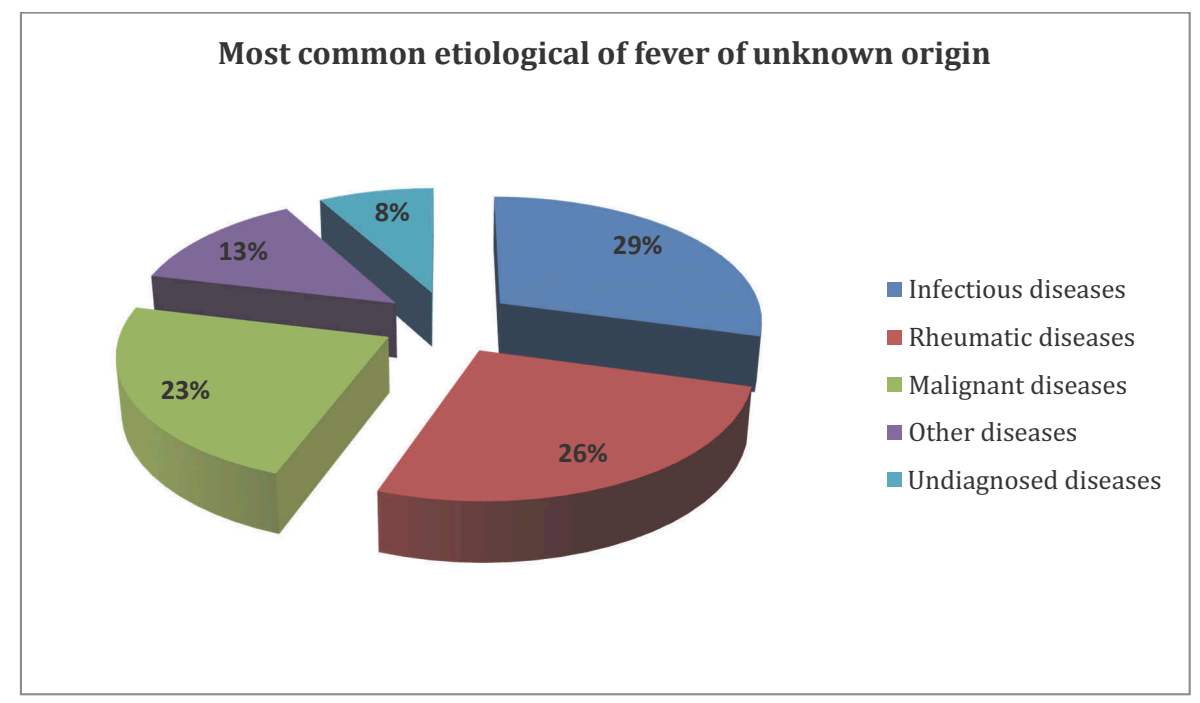

Figure 1. TNF $\alpha$ values in sera of FUO patients vs. Control group.

Results are presented as average $\pm S D,{ }^{*} p<0.05,{ }^{* * *} p<0.01$

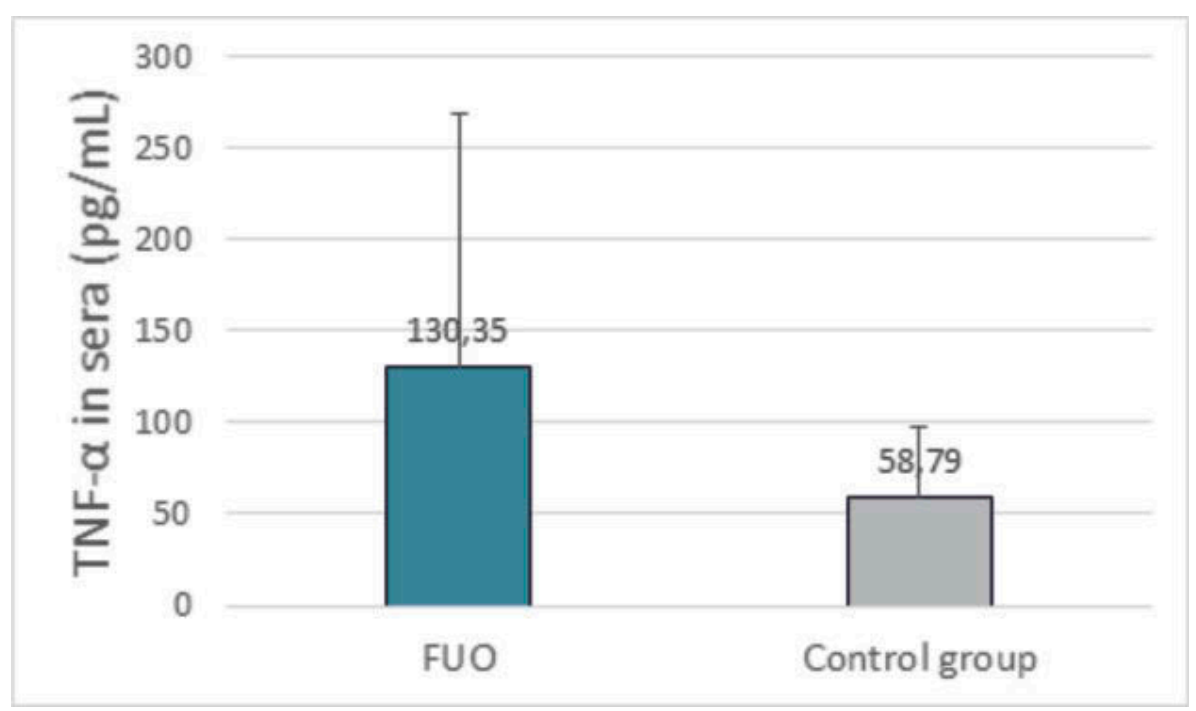

Figure 2. TNF $\alpha$ in sera among different groups of FUO patients. Results are presented as average $\pm \mathrm{SD},{ }^{*} \mathrm{p}<0.05$, ${ }^{\text {*** }} \mathrm{p}<0.01$ 


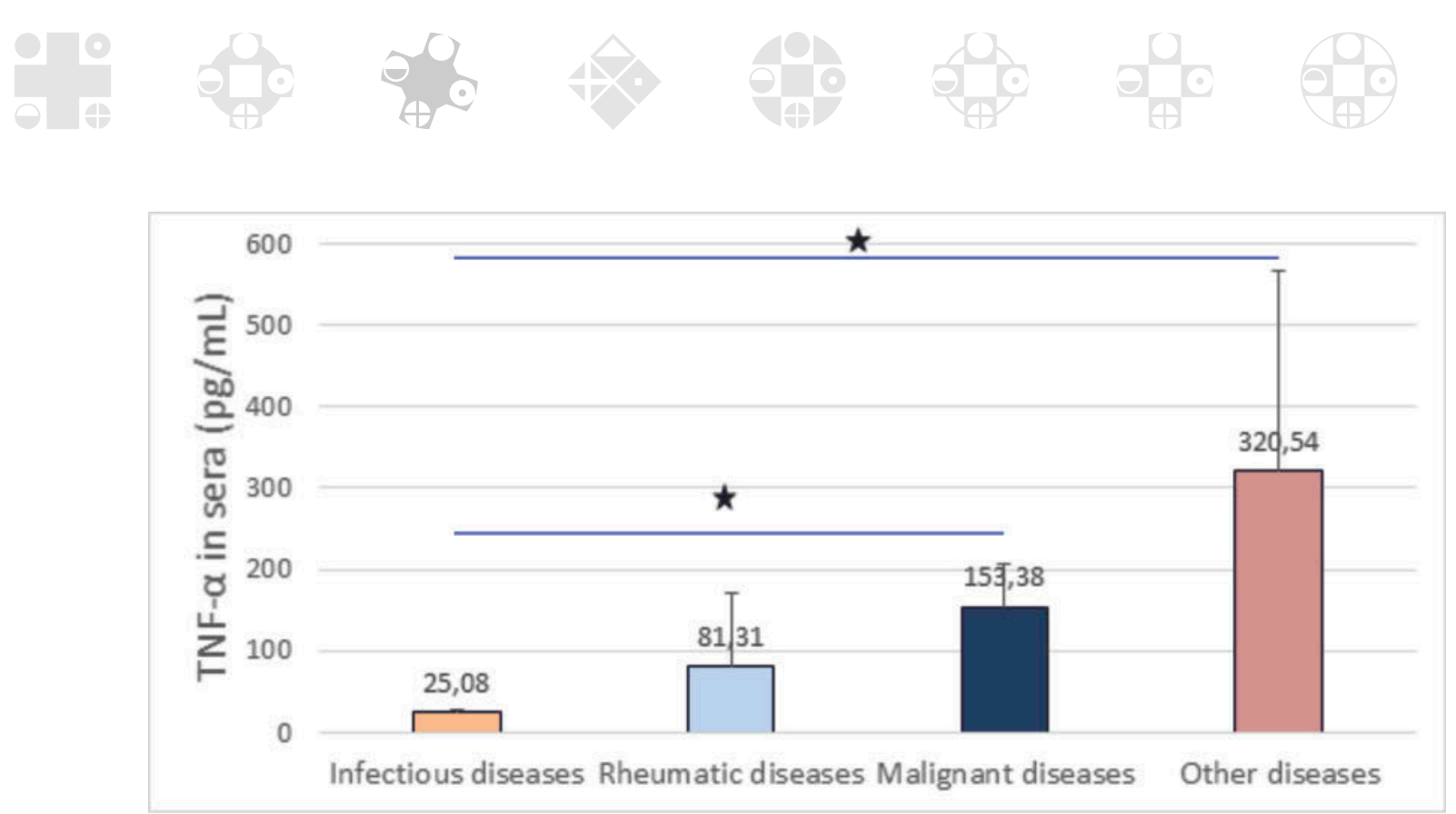

Figure 3. TNF $\alpha$ in sera among different groups of FUO patients. Results are presented as average $\pm \mathrm{SD},{ }^{*} \mathrm{p}<0.05$, ${ }^{* *} \mathrm{p}<0.01$

Serum levels of TNF $\alpha$ in the systemic circulation were significantly lower in the group of infectious diseases, as compared to the group of patients with malignant diseases and other diseases. (Figure 3).

The highest levels of TNF $\alpha$ in a total sample of FUO patients have been observed in a patient suffering from Castleman's disease, assigned to a group of other diseases, in which maximum values of this pro-inflammatory mediator were registered.

By the analysis of level IL- 6 in the serum, high values in patients with acute infectious diseases were registered compared to FUO patients but without reaching any statistical significance. Average values of five etiological patient groups were approximately equal.

\section{DISCUSSION}

In recent decades there have been numerous developments of both laboratory and visual diagnostic procedures, but the number of undiagnosed FUO patients is still approximately $10-30 \%(21,22)$. Such a high number of undiagnosed patients may be the cause of a fatal outcome, especially for those patients who hide malignancy.

Our results show that in patients with prolonged febrile condition non-infectious diseases are dominant. Most of the patients were diagnosed with some of the rheumatic or malignant diseases.

By analyzing previous studies it was observed that the distribution of etiological agents since 1961 until today has constantly been changing. In 1961 Petersdorf and Beeson announced that the largest number of patients with unknown febrile conditions has an infection or infectious diseases (36\%) (14). After infectious diseases, the leading position was occupied by malignant diseases that nowadays many authors consider as an important cause of long-term fever. More recent investigations show that a great impor- tance in the identification of the etiology of FUO has a positron emission tomography with fluoro-deoxy-glucose (FDG-PET), especially in the case of occult infections and tumor $(23,24)$.

The published results of the authors of unclear febrile conditions indicate that over the last decade a trend of increasing the number of patients with rheumatic diseases has been recognized, as shown by our results as well (25).

Although in recent decades the development of modern diagnostic procedures has occurred, febrile conditions of unidentified origin still remain a diagnostic challenge, which is why there is a constant need for a new research.

In order to evaluate FUO patients, serum concentration levels of TNF $\alpha$ with FUO patients have been measured as well as in patients with acute infectious diseases, which in the study presented a control group. Statistically speaking, significantly higher values have been achieved in the group of malignant diseases than in the group of infectious diseases.

Tumor necrosis factor is an important pro-inflammatory cytokine, which may be a link between inflammation and carcinogenic process (26). The role of TNF $\alpha$ in carcinogenesis, is reflected in the activation of the transcription factor NF-kB (27). NF-kB is responsible for the enhanced expression of genes that have a role in the survival, invasion, proliferation, angiogenesis and metastasis of tumor cells (28). In our study, in patients belonging to the group of malignant diseases breast cancer, ovarian cancer, colon cancer, etc. were diagnosed, and it is known that their tumor cells can constitutively express TNF $\alpha$. Most of the cells with these characteristics are responsible for the permanent activation of NF-kB (29).

Unlike TNF $\alpha$, other members of the TNF superfamily may have a suppressive role in tumor immunity. It was found that TRAIL can induce apoptosis in tumor or altered cells but not in case of healthy cells, causing the conducted clinical trials for the treatment of tumors (30). 
The highest levels of TNF $\alpha$ in a total sample of FUO patients have been observed in a patient suffering from Castleman's disease, assigned to a group of other diseases, in which the maximum values of this pro-inflammatory mediator are registered. Castleman's disease, a rare lymphoproliferative disorder that is defined as a localized hyperplasia of the lymph follicles with or without germinative centers, with the existence of endothelial hyperplasia (31). It is believed that in the pathogenesis of Castleman's disease a cytokine dysfunction of pro-inflammatory cytokines plays an important part, with an involvement of hypersecretion, IL-6 and TNF $\alpha$, as was the case in this study (32).

\section{CONCLUSION}

Febrile conditions of unidentified origin remain a diagnostic challenge to clinicians because it encompasses a heterogeneous group of diseases which belong to infectious illnesses and infections as well as non-infectious diseases. In view of the achieved results, determining cytokine profiles in FUO patients, can improve the diagnosis, which can shorten the duration of hospitalization, and reduce the volume of the performance of diagnostic procedures.

\section{ACKNOWLEDGMENTS}

This work was supported by grant from the Faculty of Medical Sciences, University of Kragujevac (project JP 12-14).

\section{REFERENCES}

1. Abbas AK, Lichtman AH, Pillai S. Cellular and molecular immunology. 7th. ed. Philadelphia: Elsevier, Saunders; 2012. x, 545 p. p.

2. Janeway C. Immunobiology : the immune system in health and disease. 6th ed. New York: Garland Science; 2005. xxiii, 823 p. p.

3. Murphy K, Travers P, Walport M, Janeway C. Janeway's immunobiology. 8th ed. New York: Garland Science; 2012. xix, 868 p. p.

4. Hasday JD, Thompson C, Singh IS. Fever, immunity, and molecular adaptations. Comprehensive Physiology. 2014;4(1):109-48.

5. Sugimoto Y, Narumiya S. Prostaglandin E receptors. The Journal of biological chemistry. 2007;282(16):11613-7.

6. Thelen M, Stein JV. How chemokines invite leukocytes to dance. Nature immunology. 2008;9(9):953-9.

7. Yoshimura A, Naka T, Kubo M. SOCS proteins, cytokine signalling and immune regulation. Nature reviews Immunology. 2007;7(6):454-65.

8. Malek TR. The biology of interleukin-2. Annual review of immunology. 2008;26:453-79.

9. Weaver CT, Hatton RD, Mangan PR, Harrington LE. IL-17 family cytokines and the expanding diversity of effector T cell lineages. Annual review of immunology. 2007;25:821-52.

10. Feng P, Jyotaki M, Kim A, Chai J, Simon N, Zhou M, et al. Regulation of bitter taste responses by tumor necrosis factor. Brain Behav Immun. 2015;49:32-42.

11. Starkie R, Ostrowski SR, Jauffred S, Febbraio M, Pedersen BK. Exercise and IL-6 infusion inhibit endotoxin-induced TNF-alpha production in humans. FASEB journal : official publication of the Federation of American Societies for Experimental Biology. 2003;17(8):884-6.

12. Aggarwal BB, Gupta SC, Kim JH. Historical perspectives on tumor necrosis factor and its superfamily: 25 years later, a golden journey. Blood. 2012;119(3):651-65.

13. Balkwill F. Tumour necrosis factor and cancer. Nature reviews Cancer. 2009;9(5):361-71.

14. Petersdorf RG, Beeson PB. Fever of unexplained origin: report on 100 cases. Medicine. 1961;40:1-30.

15. Durack DT, Street AC. Fever of unknown origin-reexamined and redefined. Current clinical topics in infectious diseases. 1991;11:35-51.

16. Cunha BA. Fever of unknown origin: focused diagnostic approach based on clinical clues from the history, physical examination, and laboratory tests. Infectious disease clinics of North America. 2007;21(4):1137-87, xi.

17. Ergonul O, Willke A, Azap A, Tekeli E. Revised definition of 'fever of unknown origin': limitations and opportunities. The Journal of infection. 2005;50(1):1-5.

18. Finch RG DG, Čivljak R. Fever of unknown origin. In: Begovac J BD, Lisić M, editor. Infectology. Zagreb: Profil International; 2006. p. 123-7.

19. Dinarello CA, Gatti S, Bartfai T. Fever: links with an ancient receptor. Current biology : CB. 1999;9(4):R14750.

20. Conti B, Tabarean I, Andrei C, Bartfai T. Cytokines and fever. Frontiers in bioscience: a journal and virtual library. 2004;9:1433-49.

21. Chan-Tack KM CB, Bartlett J, Sanders CV, Talavera F. Fever unknown origin: Medscape from WebMD; 2011 (cited 20128 July 2012).

22. M. P. Febrilno stanje nepoznatnog uzroka. In: bolesti Kzi, editor. Infektivne bolesti. Beograd: Medicinski fakultet Univerziteta u Beogradu; 2004. p. 387-91.

23. Bosnic D, Baresic M, Padjen I, Balenovic A, Zarkovic K, Anic B. Fever of unknown origin: large vessel vasculitis diagnosed by PET/CT. Rheumatology international. 2013;33(9):2417-21.

24. Basu S, Ranade R. 18-Fluoro-deoxyglucose-PET/Computed Tomography in Infection and Aseptic Inflammatory Disorders: Value to Patient Management. PET clinics. 2015;10(3):431-9.

25. Popovska-Jovičić B, Čanović P, Gajović O, Raković I. and Mijailović Ž. Fever of unknown origin: Most frequent causes in adults patients. Vojnosanit Pregl 2016; 73 (1): 21-25.

26. Aggarwal BB, Gupta SC, Sung B. Curcumin: an orally bioavailable blocker of TNF and other pro-inflam- 
matory biomarkers. British journal of pharmacology. 2013;169(8):1672-92.

27. Wajant H, Pfizenmaier K, Scheurich P. Tumor necrosis factor signaling. Cell death and differentiation. 2003;10(1):45-65.

28. Kant S, Swat W, Zhang S, Zhang ZY, Neel BG, Flavell RA, et al. TNF-stimulated MAP kinase activation mediated by a Rho family GTPase signaling pathway. Genes \& development. 2011;25(19):2069-78.

29. Raaschou P, Simard JF, Asker Hagelberg C, Askling J. Rheumatoid arthritis, anti-tumour necrosis factor treatment, and risk of squamous cell and basal cell skin cancer: cohort study based on nationwide prospectively recorded data from Sweden. Bmj. 2016;352:i262.
30. Sandri MT, Passerini R, Leon ME, Peccatori EA, Zorzino L, Salvatici M, Riggio D, Cassatella C, Cinieri S, and Martinelli G. Procalcitonin as a useful marker of infection in hemato-oncological patients with fever. Anticancer research 2008; 28: 3061-3066.

31. Pukac L, Kanakaraj P, Humphreys R, Alderson R, Bloom M, Sung C, Riccobene T, Johnson R, et al. "HGS-ETR1, a fully human TRAIL-receptor 1 monoclonal antibody, induces cell death in multiple tumour types in vitro and in vivo". British Journal of Cancer, 2005; 92 (8): 143041. doi:10.1038/sj.bjc.6602487

32. Barrie JR, English JC, Muller N: Castleman's disease of the lung: radiographic, high-resolution $\mathrm{CT}$, and pathologic findings. AJR Am J Roentgenol 1996; 166:1055-1056 